T.K. Philips, C.S. DeWildt, H. Davis, and R.S. Anderson - Survey of the terrestrial arthropods found in the caves of Ghana. Journal of Cave and Karst Studies, v. 78, no. 2, p. 128-137. DOI: 10.4311/2015LSC0120

\title{
SURVEY OF THE TERRESTRIAL ARTHROPODS FOUND IN THE CAVES OF GHANA
}

\author{
T. Keith Philips ${ }^{1 *}$, Chris S. DeWildt ${ }^{1,2}$, Henry Davis ${ }^{3}$, and Roger S. Anderson ${ }^{3}$
}

\begin{abstract}
The first biological inventory of the caves of Ghana was conducted during January 2006 with some subsequent work in June 2007 and July 2008. Seventy species or morphospecies of insects, as well as amblypigids, phalangids, and diplopods were discovered in sixteen caves. All taxa appear to be either troglophilic or accidental and the most abundant and richest insect faunas were found in caves with resident bat populations. Insect diversity in caves consists mainly of species of cockroaches, cave crickets, tenebrionid beetles, reduviid assassin bugs, and ants. All caves surveyed are briefly described, coordinates documented, and a list of all the arthropods discovered is also given.
\end{abstract}

\section{INTRODUCTION}

The caves of Ghana have never been sampled for their biodiversity; no faunal survey, list of taxa, or other scientific publication on any aspect of the invertebrate cave fauna of this country exists. In stark contrast and surprisingly, cave research has been conducted in every one of the surrounding countries, including Burkina Faso, Togo, and Côte d'Ivoire, as well as Guinea (Juberthie and Decu, 2001), and has resulted in novel discoveries. For example, a cave in Burkina Faso produced a new species of dytiscid beetle (Bourgies and Juberthie, 2001). In a Guinean cave, a new genus and species of blaberid cockroach was discovered and described (Roth and Naskrecki, 2004). Outside of West Africa, several publications by Villers $(1953,1973,1976)$ described the Reduviidae fauna of African caves, including one new genus, in the Belgian Congo (Democratic Republic of the Congo), Kenya, and South West Africa (Namibia).

The apparent lack of research on Ghana caves was the incentive for conducting this study as a contribution to the knowledge of cave biodiversity found worldwide. This research is also part of an effort in surveying the threatened insect fauna found in the Upper Guinean Forests of West Africa (Critical Ecosystem Partnership Fund, n.d.; Conservation International, n.d.), as well as that found in the drier savannah bush in the central and northern regions. The Guinean forests of West Africa are one of approximately 35 regions that have been recognized as global biodiversity hotspots. These hotspots make up only $2.3 \%$ of the total land area on the planet but hold an estimated $44 \%$ of plants and $35 \%$ of the land-vertebrate species (Harrison and Pearce, 2001). In contrast, the invertebrate fauna is poorly known. Hence, as part of an overall insect fauna survey of this country and the larger hotspot and to support conservation efforts, all of the known caves of Ghana were sampled for their insect faunas, as well as other arthropods.

One should note that the caves of this region are not extensive in length or depth, and none of the invertebrate fauna collected are likely either cave-limited or cave-adapted species known as troglobites; all appear to be either troglophiles or accidentals (Howarth, 1983), and it is possible that all species we report can be found outside of cave habitats. Further, no maps for any of these caves are known to exist. Regardless, this list is a first effort to put on record the insects found in Ghanaian caves and to more broadly encourage research on the relatively neglected and highly threatened insect fauna of this region.

\section{Materials ANd Methods}

Some of the caves sampled for study were known to scientific contacts in Ghana. Other caves were discovered by asking villagers in many locations about the possible presence of any caves in the vicinity and by searching the World Wide Web. Insects and other arthropods were collected throughout the various subterranean habitats in the caves by searching and hand-collecting using various tools, including aspirators and forceps. The four co-authors continued their investigation in each cave until available habitats, such as under rocks and wood or on walls or in crevices, were gleaned and no additional species could be found. On two occasions pitfalls baited with peanut butter were set in caves for about 24 hours to further sample the fauna. Fieldwork took place during an extensive threeweek survey in January 2006, with smaller surveys in June 2007 (a repeat of the Shai Hills, Sayu Cave) and July 2008 (never-before-sampled Tengzu Caves). Throughout most of Ghana, June-July and September-October are the rainy seasons, with the former the wettest. In the north, the rainfall increases from January through to a peak in September, with a steep decline through the rest of the year. In Ghana, January is a period of low seasonal rainfall throughout the country, and in some areas sampled in 2006 several species of deciduous trees had lost their leaves. Cave descriptions

\footnotetext{
* Corresponding author: keith.philips@wku.edu

${ }^{1}$ Systematics and Evolution Laboratory, Department of Biology, Western Kentucky University, Bowling Green KY 42101-3576, USA

${ }^{2}$ Current Address: 5762 S. Lady Slippery Pl., Tucson AZ 85747, USA

${ }^{3}$ Department of Animal Biology and Conservation Science, University of Ghana, P.O. Box 67, Legon, Accra, GHANA
} 
T.K. Philips, C.S. DeWildt, H. Davis, and R.S. Anderson

Table 1. List of caves in which collections were made, their coordinates, elevation, and number of taxa collected.

\begin{tabular}{|c|c|c|c|c|c|}
\hline \multirow[b]{2}{*}{ Cave } & \multirow[b]{2}{*}{ Region } & \multicolumn{2}{|c|}{ Coordinates } & \multirow[b]{2}{*}{ Elevation, m } & \multirow[b]{2}{*}{ No. of Taxa Collected } \\
\hline & & Latitude & Longitude & & \\
\hline Kaese & Eastern & $\sim \mathrm{N} 6^{\circ} 38.383^{\prime}$ & W $1^{\circ} 24.674^{\prime}$ & 580 & 7 \\
\hline Kyireabe & Eastern & $\sim \mathrm{N} 6^{\circ} 38.383^{\prime}$ & W $1^{\circ} 24.674^{\prime}$ & 580 & 4 \\
\hline Wiafe & Eastern & $\sim \mathrm{N} 6^{\circ} 38.383^{\prime}$ & W $1^{\circ} 24.674^{\prime}$ & 580 & 3 \\
\hline Mframaboum & Ashanti & $\mathrm{N} 7^{\circ} 0.217^{\prime}$ & $\mathrm{W} 1^{\circ} 18.016^{\prime}$ & 413 & 14 \\
\hline Mprisi & Ashanti & N $7^{\circ} 43.417^{\prime}$ & W $1^{\circ} 59.282^{\prime}$ & 420 & 9 \\
\hline Water & Ashanti & N $7^{\circ} 43.845^{\prime}$ & $\mathrm{W} 1^{\circ} 59.261^{\prime}$ & 425 & 9 \\
\hline Akpomu Falls & Volta & N $6^{\circ} 53.068^{\prime}$ & E $0^{\circ} 27.936^{\prime}$ & 480 & 4 \\
\hline Kokosiaba, dry & Volta & $\mathrm{N} 6^{\circ} 48.510^{\prime}$ & E $0^{\circ} 23.153^{\prime}$ & 430 & 12 \\
\hline Kokosiaba, moist & Volta & $\mathrm{N} 6^{\circ} 48.510^{\prime}$ & E $0^{\circ} 23.153^{\prime}$ & 430 & 7 \\
\hline Likpe Cave 3 & Volta & N 7 $9.850^{\prime}$ & E $0^{\circ} 36.491^{\prime}$ & 626 & 16 \\
\hline Likpe Cave 5 & Volta & N 7⒐892' & E $0^{\circ} 36.537^{\prime}$ & 615 & 7 \\
\hline Obom & Volta & N 5 59.815' & $\mathrm{W} 0^{\circ} 11.015^{\prime}$ & 246 & 12 \\
\hline Sayu (Bat/Chief) & Greater Accra & N 5 55.793' & $\mathrm{E} 0^{\circ} 03.431^{\prime}$ & 160 & 13 \\
\hline
\end{tabular}

and only approximate size estimations are given, as precise mapping of the caves was not a goal of this project.

Specimen identifications were made by the first two authors to as low a level as accurately possible using literature and websites such as AntWiki (http://www.antwiki.org/ wiki/Ghana). Attempts were made to procure more specific and accurate determinations from specialists as much as possible. It is our hope that this paper may interest insect systematists in studying specimens that were collected during this project. Hence all vouchers collected are available for study and are currently deposited in the T. K. Philips Collection (Western Kentucky University), with the exception of the Reduviidae that are in the B. D. Gill Collection (Ottawa, Canada). It is hoped that the eventual depository for most of the specimens from this study and from other collections will be the developing National Insect Collection at the Department of Animal Biology and Conservation Science at the University of Ghana, currently located in the African Regional Postgraduate Program in Insect Science (ARPPIS) on the main campus in Legon.

As the cave faunas of Ghana do not seem to be characterized morphologically as troglobites (species restricted to cave habitats with morphological features such as loss of eyes and pigmentation) and there are no collection records outside of the caves to determine if most of the species are either trogloxenes (species that regularly enter caves but leave periodically for certain living requirements) or accidentals (species rarely found in caves and not making any real use of the habitat), we have left off these designations as defined by Romero (2009). Notes are given for caves that appear to be well known as such, but actually are only caves by the broadest definition possible, such as Abutia Cave and Kpando Blue Uzs Grotto, and where no particular fauna were observed. They are reported in order to save time and effort for those wishing to further explore and sample the faunas of the true caves found in Ghana.
One should be aware that typically permission is first needed from the nearest village chief or the village elders before one can gain cave entry. While the caves at Likpe are commercial, at the other caves a local person can serve as a guide for some monetary compensation, usually negotiated in advance, for his services. Once at the cave entrance, it may also be necessary to perform a ceremony, referred to as libations, in which alcohol, typically schnapps, is poured onto the ground while prayers are recited in a short ceremony of ancestor worship. The true caves from which taxa were collected and their locations are listed in Table 1. All sites investigated are described in the following section.

\section{Cave Descriptions}

\section{EASTERN REGION}

Caves explored in this region are all situated near the town of Abesua $\left(\mathrm{N} \mathrm{6}^{\circ} 38.383^{\prime} \mathrm{W} 1^{\circ} 24.674^{\prime} ; 583 \mathrm{~m}\right)$. A short drive from the main road was taken to an area near the base of a hill, and one must hike to visit the four caves. The entire process of surveying all the sites took about six hours.

Kyireabe Cave. This rock shelter consists of an overhang that protects a small cavity in the rock face that extends in approximately $3.5 \mathrm{~m}$. The cavity is high enough to stand up in. Accumulated seeds that had been carried in by rodents and eaten were observed. There did not seem to be an associated cave fauna, and the cavity was very dry.

Kaasi Cave. This cave is located on a steep hill with an entrance about $2 \mathrm{~m}$ high and $1 \mathrm{~m}$ wide. The cave extends in approximately 10 to $15 \mathrm{~m}$. The floor at the entrance immediately begins to slope down for three-quarters of the length. The walls angle in and meet at the ceiling, which in some places is about $5 \mathrm{~m}$ high. There is also a second, smaller passage about $2 \mathrm{~m}$ up near the end of the main passage. Bats are present, and this was the only cave of the four in this area with cave crickets (Phaeophilacris sp.). 


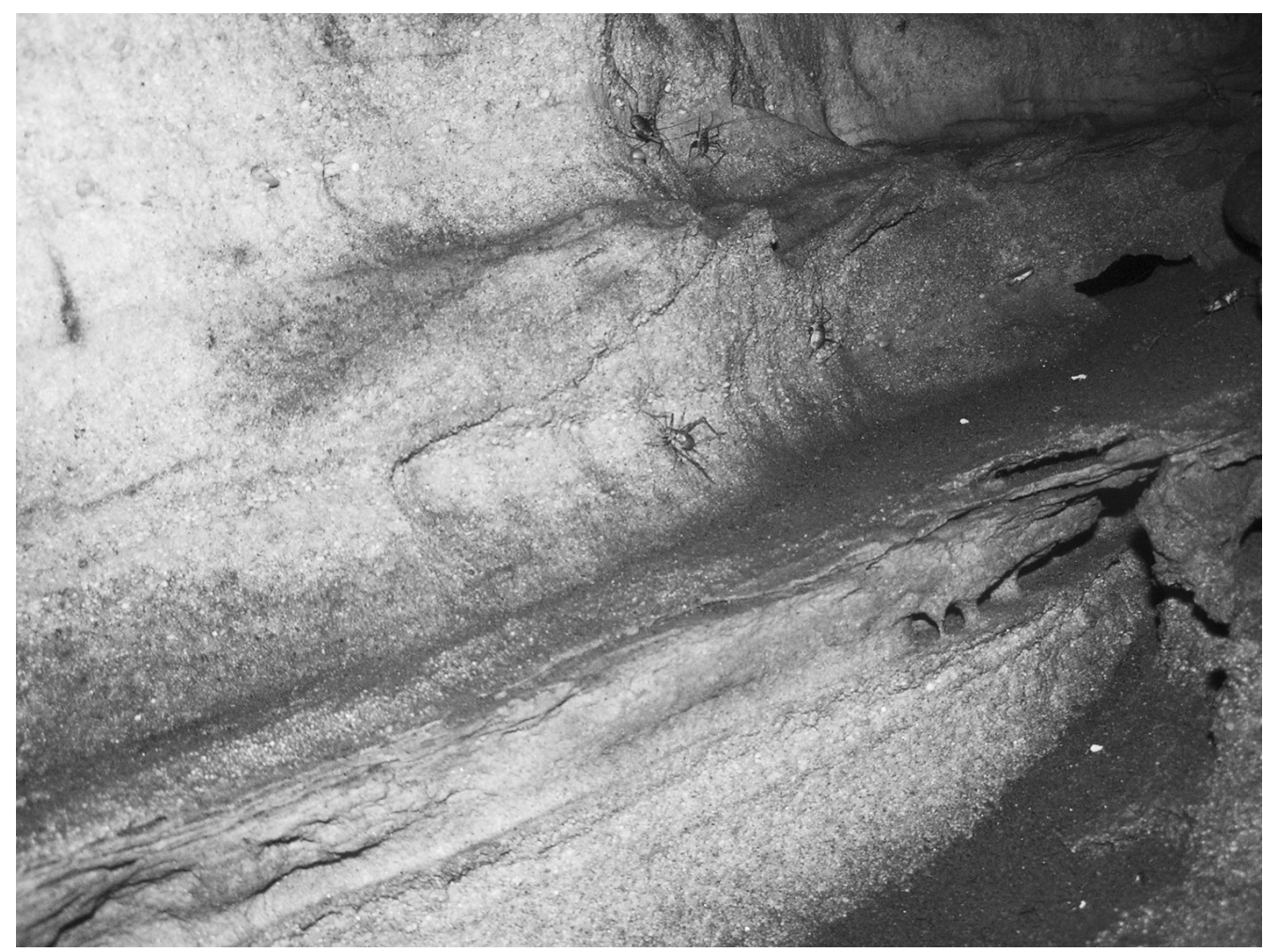

Figure 1. Cave crickets (Phaeophilacris sp.) on a wall in Mframaboum Cave.

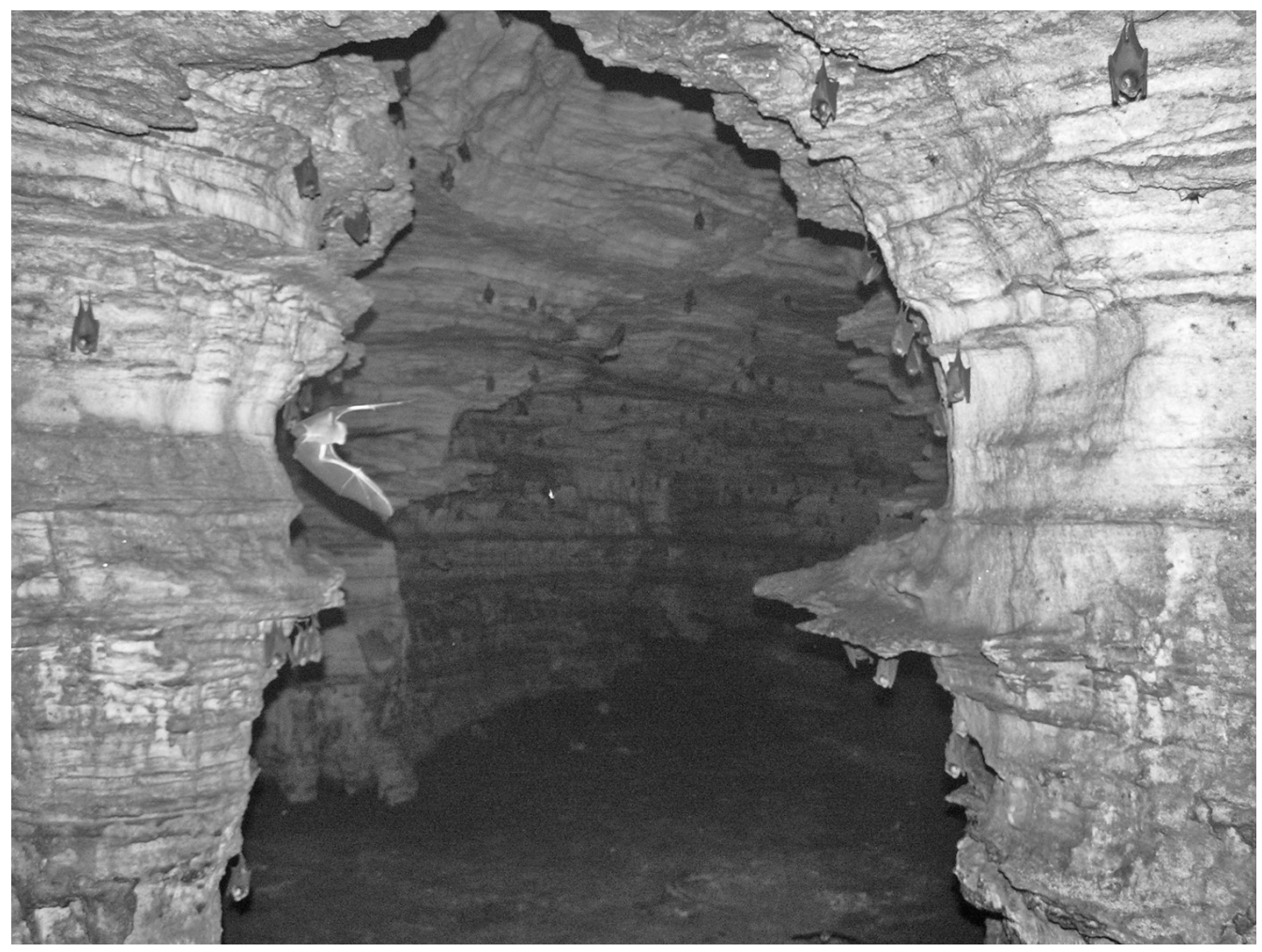

Figure 2. The main passage in Mframaboum Cave. 


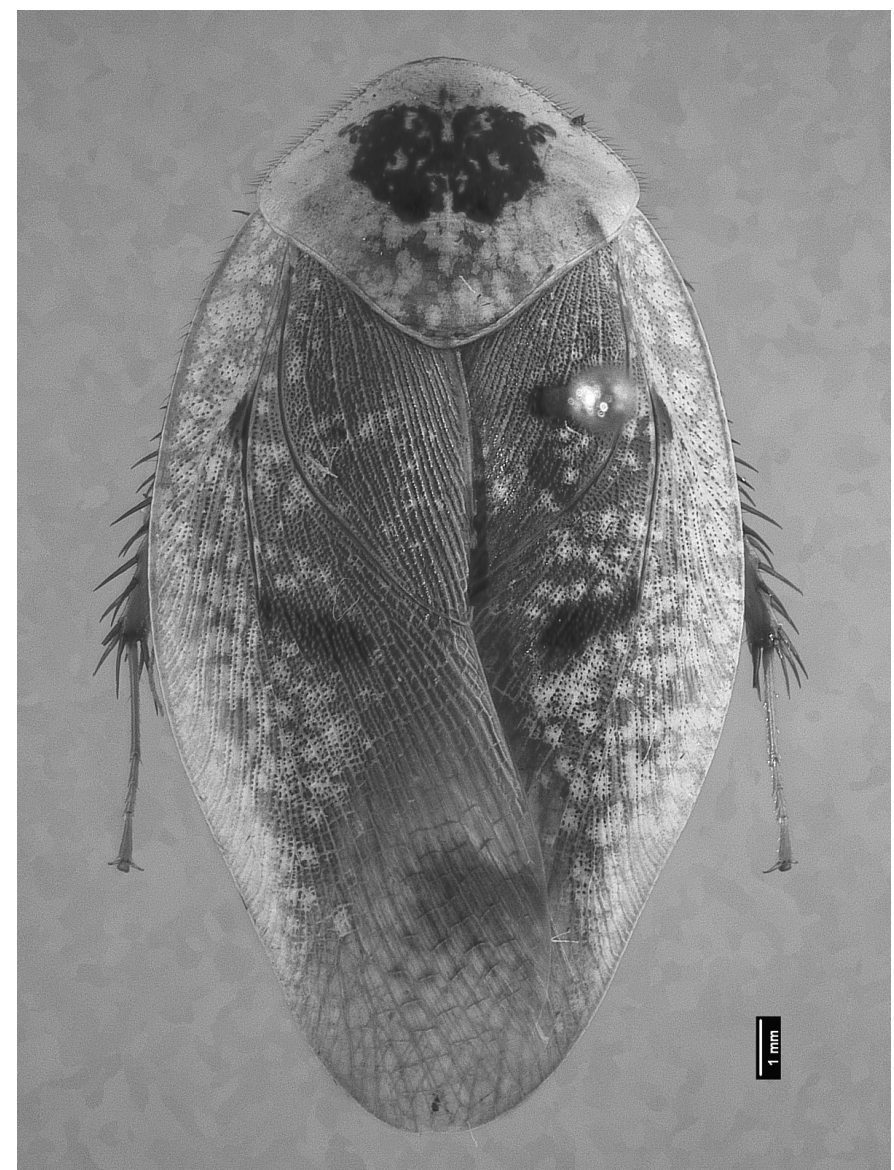

Figure 3. Dorsal habitus of a cockroach belonging to the Gyna maculipennis group collected in Mframaboum Cave.

Prati Cave. This is only a small rock shelter without a cave fauna.

Wiafe Cave. Reaching this cave entails a steep climb, including passing over large rocks. The entrance is in a vertical rock face, is about $0.75 \mathrm{~m}$ wide and over $4 \mathrm{~m}$ in height, and leads to about $5 \mathrm{~m}$ of passage to a drop about $2.75 \mathrm{~m}$ onto a wet muddy floor.

\section{Ashanti Region}

Mframaboum Cave (N 7 $\left.0.217^{\prime}, \mathrm{W} 1^{\circ} 18.016^{\prime} ; 413 \mathrm{~m}\right)$. This cave is accessed via a short hike of about $200 \mathrm{~m}$ from a road. The cave consists of a main chamber that intersects several additional secondary chambers. The air inside the cave was extremely humid, and bats were abundant with one small chamber that contained more than 90 bats (Fig. 1 and Fig. 2). There was a large chamber immediately behind the main chamber, and there was a shallow stream running the entire length $(7 \mathrm{~m})$. Platyhelminth flatworms were present and common in the stream detritus. This stream continued through several sub-chambers and through a passage in the wall of the cave, emerging outside to the right side of the cave entrance as a small waterfall. Twenty pitfall traps were set in the silt of the cave, 5 in small passage and

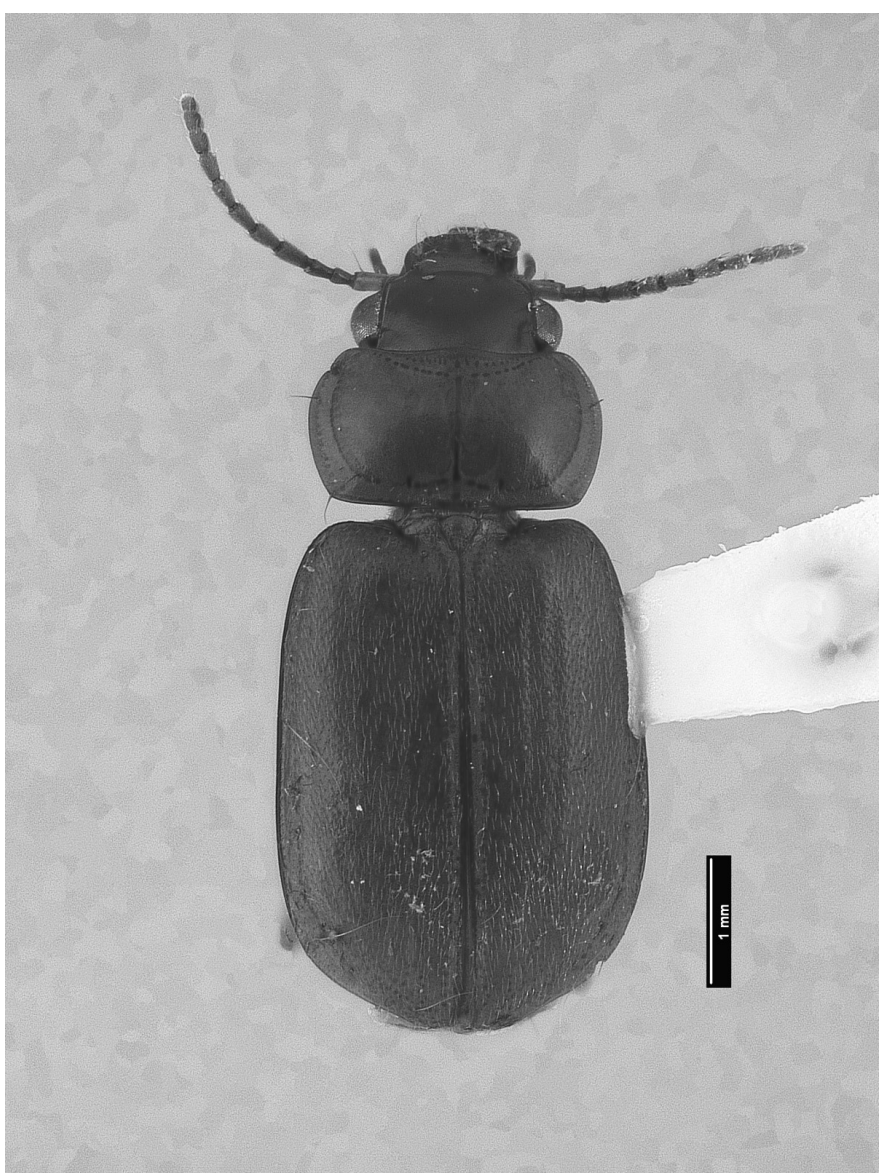

Figure 4. Dorsal habitus of an undetermined species of ground beetle (Carabidae, Masoreini) found in Mframaboum Cave, Water Cave, Ancestral Caves at Likpe Todome \#3, and both the Kokosiaba Dry and Moist Caves.

15 in the main chamber. Rodent disturbance of the 5 smallpassage traps made collection impossible. Several other traps were found filled with dry, powdery detritus, common in these caves. Its presence was most likely due to activity of "dust or guano swimmers," a group of cave cockroaches (Fig. 3 and Fig. 4) that engage in an interesting ambulatory "swimming" movement through guano dust and detritus. Traps did not result in the collection of any additional species.

Water Cave (N 7 $43.845^{\prime}$ W $1^{\circ} 59.261^{\prime}$; $425 \mathrm{~m}$; near Buoyem). The cave entrance is about $20 \mathrm{~m}$ wide and more than $4 \mathrm{~m}$ in height and arches down towards the sides. A large termite mound approximately $7 \mathrm{~m}$ in diameter at the base currently divides the entrance almost directly in the center. The interior can be divided into two separate regions. Initially inside is a very large, dry room. A stream runs from the back of the cave, exiting out the left side of the entrance. The ceiling of this first room gradually slopes down the length of the room, leveling off at about $1 \mathrm{~m}$ high some $6.5 \mathrm{~m}$ into the cave. This lower section continues about $5 \mathrm{~m}$ to where the ceiling abruptly rises into the second, slightly smaller chamber. Water running into this second chamber from the ceiling is the source of the stream in the cave. 


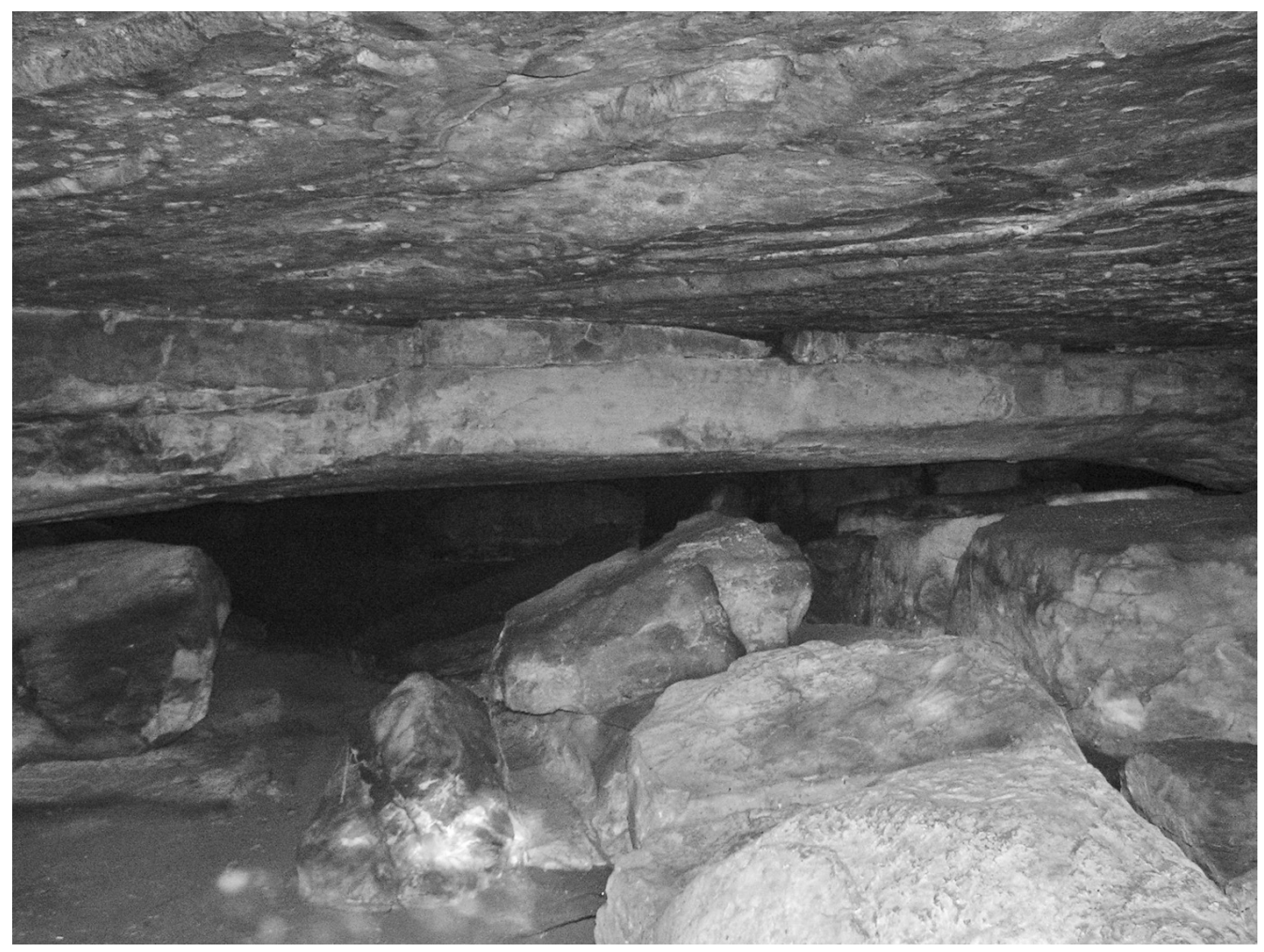

Figure 5. Mprisi Cave near the entrance.

Mprisi Cave (N 743.417' W 159.282'; 420 m; near Buoyem; also known as the "Don't rush and enter cave"). This cave is mostly dry at the entrance, with much powdery detritus at least $5 \mathrm{~cm}$ deep covering the floor (Fig. 5). The rear of the cave is very moist, with a small waterfall flowing from the ceiling. Guano accumulations in this area are as deep as $0.75 \mathrm{~m}$ (Fig. 6). Many megachiropterans and microchiropterans utilize this cave, and a pungent and somewhat overwhelming odor of ammonia is present.

Abutia Cave (N 6 $\left.{ }^{\circ} 58.881^{\prime} \mathrm{W} 1^{\circ} 16.446^{\prime} ; 475 \mathrm{~m}\right)$. This is not a cave, but consists only of a water seep at the base of a cliff face. This spring is used as a water source for the people in the town of Kwamang.

\section{Volta Region}

Ancestral Caves at Likpe Todome. This set of caves is located $14 \mathrm{~km}$ east of Hohoe-Likpe Mate Road at the western foot of Todome Hill. This hill is part of the AkwapinTogo Mountain Range. These caves appear to be formed within dolomite. Caves \#1 and \#2 are both small, elongate caves and no arthropods were detected in either one. Village elders used the first cave for meetings during regional wars, while the second cave was used as a watchtower. Cave \#3 (N 79.850' E $0^{\circ} 36.491^{\prime} ; 626 \mathrm{~m}$ ) is a slightly larger cave with a relatively large fauna, likely due to high numbers of accidentals as well as the presence of bats. This cave was once used as a hideout during times of tribal war. Cave \#4 consists of a single chamber with a chimney that angles steeply upward. This cave is said to have been used for private consultations with elders. The chimney could serve as a passage for the king to escape in the event of an ambush. No biota was observed. Cave \#5 (N 79.892' E $0^{\circ} 36.537^{\prime}$; $615 \mathrm{~m}$ ) consists of a relatively narrow tunnel, with a side chamber, that is approximately $5 \mathrm{~m}$ in length. This cave previously has been used as a holding cell for criminals.

Akpomu Falls (Eagle Pool) (N 6 53.068' E 0 27.936'; 480 $\mathrm{m})$. The cave is in the vicinity of a $25 \mathrm{~m}$ high waterfall and large pool. The cave is a small cavity to the left of waterfall. A chimney near the entrance extends about $6 \mathrm{~m}$ vertically. Though it is rich in moisture, no cave fauna was discovered.

Kokosiaba Caves (N 6 48.510' $\mathrm{E}$ 0 ${ }^{\circ} 23.153^{\prime}$; 430 m; near Nyagbo Konda) are two caves without separate local names, but they are easily distinguished by the level of moisture present and can be referred to as Dry Cave (the first cave reached) and Moist Cave. These caves are accessible via the town of Agodome ( $6^{\circ} 48.597^{\prime}$ E $0^{\circ} 23.339^{\prime} ; 460 \mathrm{~m}$ ). A hike of about $280 \mathrm{~m}$ up to the top of the ridge leads to village of Nyagbo Konda. An additional short hike south of the village, skirting the hillside leads to the caves. Both caves are located about $600 \mathrm{~m}$ from the village. Dry Cave was completely dry during our visit, and it is notable for the presence of an unidentified purple-colored mineral. The cave entrance is accessible via a $2.5 \mathrm{~m}$ climb up a vertical rock face and is large, round in shape, and easily accessible. The cave consists of a tubular passage about $8 \mathrm{~m}$ in depth. At the end of the passage on left is a crevice that 


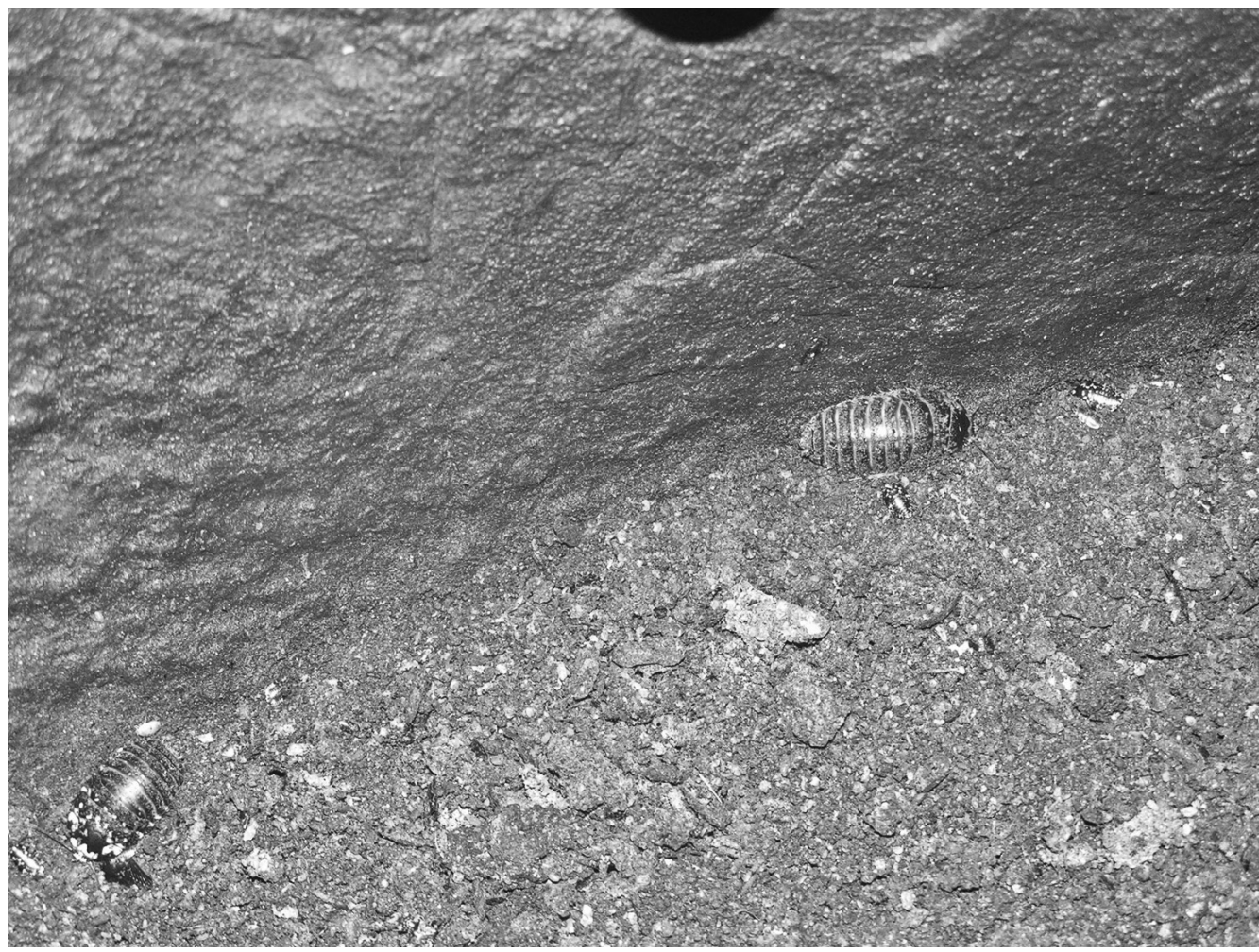

Figure 6. Cockroaches belonging to the Gyna maculipennis group in the cave floor litter composed of dry bat guano in Mprisi Cave.

opens to the opposite side near the access trail. Moist Cave is short walk farther down the trail. The cave is circular, with a round entrance approximately $2 \mathrm{~m}$ in diameter, and is very moist inside, no doubt in part from bat urine. It extends at least $25 \mathrm{~m}$ in depth, with the height gradually decreasing and becoming difficult and then impossible to access any farther. The passage also extends laterally $10 \mathrm{~m}$ or more and varies in height from as much as $0.5 \mathrm{~m}$ to as little as several 5 to $10 \mathrm{~cm}$. The cave floor is composed of a layer of firm and likely very deep guano covered by a 5 to $10 \mathrm{~cm}$ layer of loose detritus.

Obom Cave (N 5 59.815' W $\left.0^{\circ} 11.015^{\prime} ; 246 \mathrm{~m}\right)$. This cave is $500 \mathrm{~m}$ from Obom village. The opening is very wide, approximately $13 \mathrm{~m}$ across. The ceiling is low, approximately $1.3 \mathrm{~m}$ at the entrance, rapidly drops to less than $1 \mathrm{~m}$, and lowers toward the rear of cave. The total length of the cave is greater than $14 \mathrm{~m}$ in some areas, although much of the area is relatively inaccessible due to low ceiling height unless one crawls in a prone position. The cave is quite dry, although it has some moisture toward the rear.

\section{Greater Accra Region (Shai Hills \\ Resource RESERVE)}

Sayu Cave (also known as Bat Cave or Chief Cave; N $5^{\circ} 55.793^{\prime}$ E $0^{\circ} 3.431^{\prime} ; 160 \mathrm{~m}$ ). This cave is located near the top of a hill. The first part of the cave is relatively open and airy with plenty of natural light. Continuing through a crevice leads one into a second chamber composed of a $15 \mathrm{~m}$ tall slanting wall on the right side and a more vertical wall on the left, with the passage width averaging 1 to $2 \mathrm{~m}$. The slanting wall catches falling urine and guano deposited by numerous bats hanging above the floor. That wall, on the right facing in, was wet with urine, and the loose guano deposits on the floor were more than $0.5 \mathrm{~m}$ deep in some areas. In both January 2006 and June 2007, a cetoniine (Pachnoda marginata aurantia Herbst; see Orozco and Philips, 2012) and one species of tenebrionid (Tenebrio c.f. guineensis Imhoff) were numerous. In January 2006, no streblid flies (Brachytarsina spp.) were observed, while in June, they were numerous along the relatively dry left wall of the cave.

Adwuku Cave (N 555.783', E 04.992', 144 m). This cave is also near the top of a hill and is composed of a pile of large, loose rocks possibly consisting of iron-rich basalt. There is no evidence of any specific cave fauna. In January 2006 the cave was extremely arid due to the harmatan winds blowing from the north that are present during the dry season in Ghana.

Oboniten Caves (also called Hioweyo Caves; N $5^{\circ} 54$. $028^{\prime}$, E $0^{\circ} 03.992^{\prime}, 230 \mathrm{~m}$ ). There is a large cave above and a much smaller cave near the trail. The latter cave is very open. The former cave consists of a passage some $10 \mathrm{~m}$ long. Both caves were very dry, and we did not observe any cave fauna. These caves are similar to those found in Tengzu in the Upper East Region.

Kpando Blue Uzs Grotto (N 6 58.300', $\mathrm{E}^{\circ} 17.171^{\prime}, 127 \mathrm{~m}$ ). This is part of a Catholic Church shrine. This is not a true cave, but only a rock pile about 4 to $5 \mathrm{~m}$ in height 


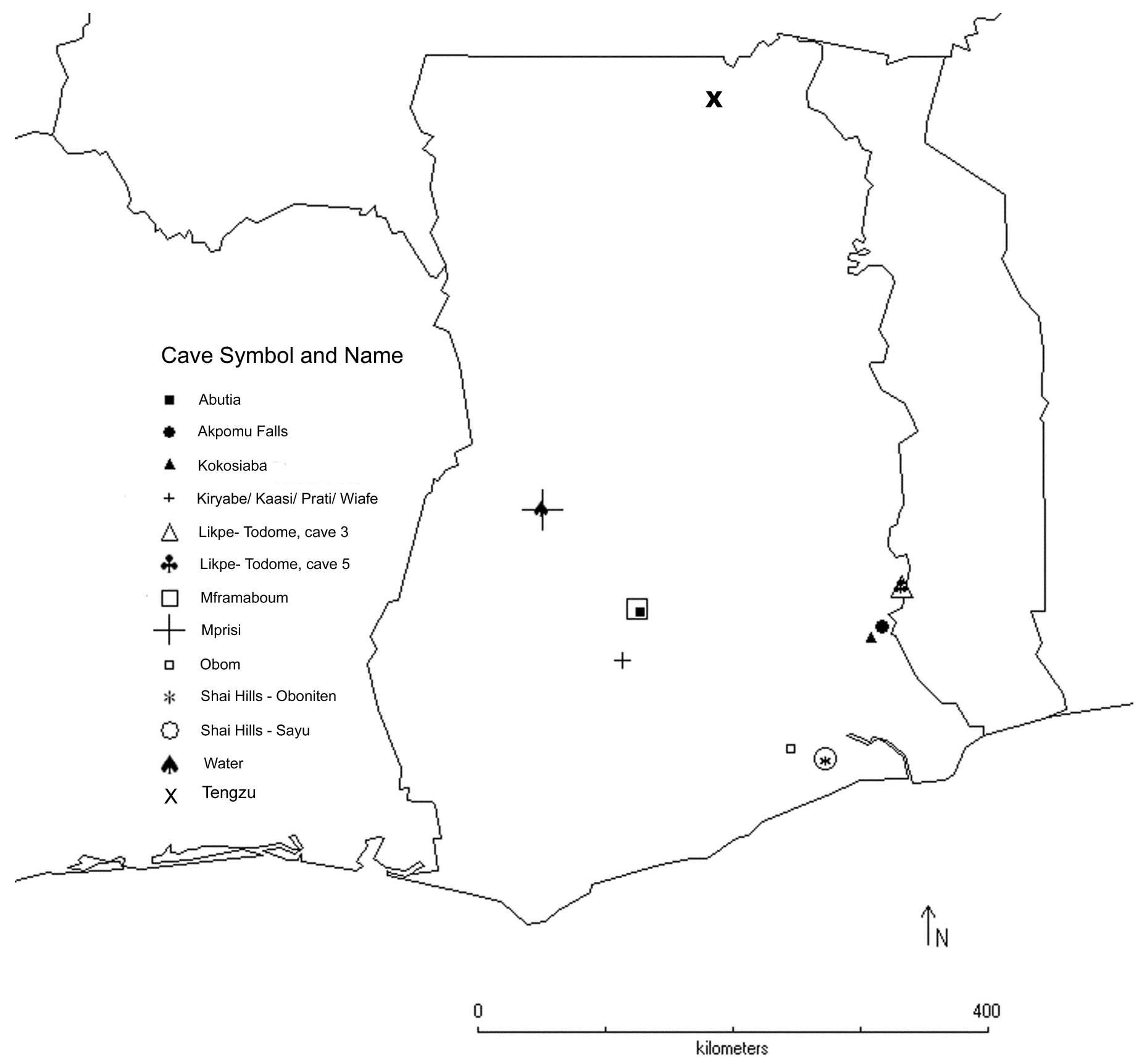

Figure 7. Location of the caves sampled in Ghana.

with a cavity that drops down vertically approximately $1 \mathrm{~m}$ and extends horizontally roughly $0.7 \mathrm{~m}$.

\section{UPPER EAST REgION}

Tengzu caves (Kpenlinne Caves, Hyena, School, Don-

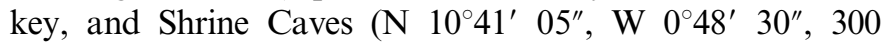
$\mathrm{m})$. These caves are perhaps better referred to as rock shelters. They are near the village of Tongo and were explored during July 2008. They consist mainly of large balanced boulders with crevices, and they lack what one would consider a true cave fauna. These caves are similar to some of those found Shai Hills in the Greater Accra Region. Of note is the presence of an undetermined and likely undescribed species of spider beetle (Ptinidae) in the genus Dignomus Wollaston that was found breeding in goat pellets within some of the shelters.

\section{Discussion}

This work is the first study on the cave fauna of Ghana. All caves known, publicized, and that we could discover were investigated for their cave faunas (Fig. 7). It is quite 
Table 2. List of taxa collected or observed in the caves of Ghana.

\begin{tabular}{|c|c|}
\hline Organism & Cave \\
\hline \multicolumn{2}{|l|}{ Vertebrata } \\
\hline Chiroptera & $\begin{array}{l}\text { Mframaboum Cave, Mprisi Cave, Ancestral Caves at Likpe Todome Cave \#3, } \\
\text { Ancestral Caves at Likpe Todome \#5, Sayu Cave (Bat Cave or Chief Cave) }\end{array}$ \\
\hline \multicolumn{2}{|l|}{ Invertebrata } \\
\hline $\begin{array}{l}\text { Amblypigida sp. (only } \\
\text { observed) }\end{array}$ & Kaasi Cave, Wiafe Cave Ancestral Caves at Likpe Todome \#5 \\
\hline Phalangida sp. & Kaasi Cave \\
\hline Diplopoda sp. & Kyireabe Cave (Eastern region), Kokosiaba Dry Cave \\
\hline Thysanura sp. $1 \& 2$ & Obom Cave \\
\hline \multicolumn{2}{|l|}{ Blattodea } \\
\hline $\begin{array}{l}\text { Blaberidae: Gyna } \\
\text { maculipennis } \\
\text { group }\end{array}$ & $\begin{array}{l}\text { Kyireabe Cave (Eastern Region), Mframaboum Cave, Water Cave, Mprisi Cave } \\
\text { Ancestral Caves at Likpe Todome \#3, Ancestral Caves at Likpe Todome \#5, } \\
\text { Kokosiaba Dry Cave, Obom Cave, Sayu Cave (Bat Cave or Chief Cave) }\end{array}$ \\
\hline Blaberidae: Rhabdoblatta sp. & Akpomu Falls \\
\hline Polyphagidae: Tivia sp. & Sayu Cave (Bat Cave or Chief Cave) \\
\hline $\begin{array}{l}\text { Polyphagidae: } \\
\text { Euthyrrhapha sp. }\end{array}$ & Kokosiaba Moist Cave \\
\hline \multicolumn{2}{|l|}{ Coleoptera } \\
\hline Anthicidae sp. & $\begin{array}{l}\text { Ancestral Caves at Likpe Todome \#3, Ancestral Caves at Likpe Todome \#5, } \\
\text { Kokosiaba Moist Cave }\end{array}$ \\
\hline Buprestidae sp. & Kokosiaba Dry Cave \\
\hline Carabidae, Masoreini sp. & $\begin{array}{l}\text { Mframaboum Cave, Water Cave, Ancestral Caves at Likpe Todome \#3, Kokosiaba } \\
\text { Dry Cave, Kokosiaba Moist Cave }\end{array}$ \\
\hline $\begin{array}{l}\text { Cetoniidae: Pachnoda } \\
\text { marginata } \\
\text { aurantia } \text { Herbst }\end{array}$ & Sayu Cave (Bat Cave or Chief Cave) \\
\hline Chrysomelidae sp. 1 & Water Cave \\
\hline Chrysomelidae sp. 2 & Kokosiaba Dry Cave \\
\hline Dermestidae sp. & Ancestral Caves at Likpe Todome \#3, Obom Cave \\
\hline Elateridae sp. & Mframaboum Cave, Kokosiaba Dry Cave \\
\hline Euglenidae sp. & Ancestral Caves at Likpe Todome \#3, Kokosiaba Moist Cave \\
\hline Histeridae sp. 1, 2 and 3 & Mframaboum Cave \\
\hline Histeridae sp. 4 & Mprisi Cave \\
\hline Hydrophilidae sp. 1 & Mframaboum Cave, Sayu Cave (Bat Cave or Chief Cave) \\
\hline Hydrophilidae sp. 2 and 3 & Akpomu Falls \\
\hline Hydrophilidae sp. 4 & Mframaboum Cave \\
\hline Hydrophilidae sp. 5 & Sayu Cave (Bat Cave or Chief Cave) \\
\hline Lampyridae sp. & Mprisi Cave \\
\hline Scymaenidae sp. & Kaasi Cave \\
\hline $\begin{array}{l}\text { Staphylinidae: } \\
\text { Scaphidiinae sp. }\end{array}$ & Kaasi Cave, Wiafe Cave \\
\hline $\begin{array}{l}\text { Tenebrionidae: Tenebrio c.f. } \\
\text { guineensis Imhoff }\end{array}$ & Mprisi Cave, Sayu Cave (Bat Cave or Chief Cave) \\
\hline Tenebrionidae sp. 2 & Sayu Cave (Bat Cave or Chief Cave) \\
\hline Throscidae sp. & Ancestral Caves at Likpe Todome \#3 \\
\hline \multicolumn{2}{|l|}{ Diptera } \\
\hline Calypterate Diptera sp. & Sayu Cave (Bat Cave or Chief Cave) \\
\hline Chironomidae sp. & Water Cave, Mprisi Cave, Ancestral Caves at Likpe Todome \#5 \\
\hline Psychodidae sp. & Mframaboum Cave, Water Cave, Mprisi Cave \\
\hline Streblidae: Brachtarsina sp. & Ancestral Caves at Likpe Todome \#3, Obom Cave, Sayu Cave (Bat Cave or Chief Cave) \\
\hline Tipulidae or near sp. & Water Cave, Obom Cave \\
\hline \multicolumn{2}{|l|}{ Hemiptera } \\
\hline Gerridae sp. & Mframaboum Cave \\
\hline
\end{tabular}


Table 2. Continued.

\begin{tabular}{|c|c|}
\hline Organism & Cave \\
\hline Lygaeidae sp. & Kaasi Cave \\
\hline Naucoridae sp. & Mframaboum Cave \\
\hline Anthocoridae? nymph & Kaasi Cave \\
\hline Reduviidae sp. (nymph) & Wiafe Cave \\
\hline $\begin{array}{l}\text { Reduviidae: Hermillus } \\
\text { geniculatus (Sign.) }\end{array}$ & Ancestral Caves at Likpe Todome \#3 \\
\hline Reduviidae sp. (nymph) & Ancestral Caves at Likpe Todome \#5 \\
\hline $\begin{array}{l}\text { Reduviidae: Cethera } \\
\text { cornifrons } \text { Villiers }\end{array}$ & Kyireabe Cave (Eastern Region) \\
\hline $\begin{array}{l}\text { Reduviidae: Stenopodainae } \\
\text { (missing head) }\end{array}$ & Mframaboum Cave \\
\hline $\begin{array}{l}\text { Reduviidae: Ectrichodia } \\
\quad \text { lucida (L. \& S.) }\end{array}$ & Obom Cave \\
\hline $\begin{array}{l}\text { Reduviidae: Lhostella } \\
\text { congoensis (Lhoste) }\end{array}$ & Obom Cave \\
\hline $\begin{array}{l}\text { Reduviidae: Myiophanes } \\
\text { leleupi Villiers? }\end{array}$ & Ancestral Caves at Likpe Todome \#3 \\
\hline Reduviidae Hermillus sp. & Kokosiaba Moist Cave \\
\hline Reduviidae: Emesinae sp. & Mprisi Cave \\
\hline \multicolumn{2}{|l|}{ Hymenoptera } \\
\hline Apidae: Meloponinae sp. & Kokosiaba Dry Cave \\
\hline Formicidae: Tetramorium sp. & Mframaboum Cave, Water Cave, Sayu Cave (Bat Cave or Chief Cave) \\
\hline Formicidae: Messor sp. & Sayu Cave (Bat Cave or Chief Cave) \\
\hline $\begin{array}{l}\text { Formicidae: Camponotus } \\
\text { sp. } 1\end{array}$ & Ancestral Caves at Likpe Todome \#3 \\
\hline Formicidae: Cematogaster sp. & Kokosiaba Dry Cave \\
\hline $\begin{array}{l}\text { Formicidae: Camponotus } \\
\text { sp. } 2\end{array}$ & Kokosiaba Dry Cave, Obom Cave \\
\hline Formicidae: Ponerinae? & Ancestral Caves at Likpe Todome \#3 \\
\hline $\begin{array}{l}\text { Formicidae: } \\
\quad \text { Cardiocondyla sp. }\end{array}$ & Ancestral Caves at Likpe Todome \#5 \\
\hline Formicidae: Dorylus sp. & Mprisi Cave \\
\hline Formicidae: Polyrhachis sp. & Kokosiaba Dry Cave \\
\hline Formicidae: Megaponera sp. & Sayu Cave (Bat Cave or Chief Cave) \\
\hline $\begin{array}{l}\text { Formicidae: Camponotus } \\
\text { sp. } 3\end{array}$ & Kokosiaba Moist Cave \\
\hline Formicidae: Bothroponera sp. & Ancestral Caves at Likpe Todome \#3 \\
\hline Scoliidae sp. & Sayu Cave (Bat Cave or Chief Cave) \\
\hline Chalcidoidea sp. & Ancestral Caves at Likpe Todome \#3 \\
\hline \multicolumn{2}{|l|}{ Lepidoptera } \\
\hline Tineidae sp. & $\begin{array}{l}\text { Mframaboum Cave, Water Cave, Ancestral Caves at Likpe Todome \#3, Obom Cave, } \\
\text { Sayu Cave (Bat Cave or Chief Cave) }\end{array}$ \\
\hline \multicolumn{2}{|r|}{ 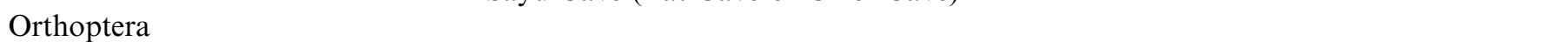 } \\
\hline $\begin{array}{l}\text { Phalangopsidae: } \\
\text { Phaeophilacris spp. }\end{array}$ & $\begin{array}{l}\text { Kyireabe Cave, Kaasi Cave, Water Cave, Mprisi Cave, Ancestral Caves at Likpe } \\
\text { Todome \#3, Ancestral Caves at Likpe Todome \#5, Akpomu Falls, Kokosiaba Dry } \\
\text { Cave, Kokosiaba Moist Cave, Obom Cave }\end{array}$ \\
\hline Gryllidae sp. & Kokosiaba Dry Cave, Obom Cave \\
\hline Psocoptera sp. & Sayu Cave (Bat Cave or Chief Cave) \\
\hline $\begin{array}{l}\text { Trichoptera (family } \\
\text { undetermined, } 2 \text { spp.) }\end{array}$ & Water Cave \\
\hline
\end{tabular}


possible that there are additional caves that are well known by the local population but not yet surveyed. Current evidence suggests, however, that it is doubtful that a much more extensive fauna exists than has been documented in this report. Further, it is likely that all the species we collected (Table 2) are either troglophiles or accidentals. No species discovered have some of the typical morphological characteristics of true troglobites, such as lack of eyes, eye pigment, or unusually long setae or antennae. Candidates for caves containing true troglobites are Mframaboum and Water Caves, as these have smaller, deeper passages that could be thoroughly explored.

As might be expected, the highest diversity was typically found in caves with good bat populations, including Mframaboum, Likpe Cave \#3, and Sayu, with 14, 16, and 13 species, respectively. Two other caves with relatively high diversity of 12 species in each were Kokosiaba Dry Cave and Obom Cave (Table 1).

The cave fauna, unsurprisingly, is very similar to that found in the surrounding countries (Juberthie and Bourgies, 2001). For example, some of the caves have dense populations of cockroaches that move in dry detritus mainly composed of bat dung in a manner best described as swimming, often diving below the surface to avoid detection. These have been described by others as "guanobies," a group of guano swimming cockroach species (Roth and Naskrecki, 2004).

Of specific interest was the relatively large number (12) of assassin-bug species (Reduviidae) found within caves that may be opportunistically feeding on large populations of cockroaches, other insects, or perhaps millipedes. Also, the record of a daytime-active cetoniine scarab beetle, a taxon that has never been reported from cave or rock shelter habitats, is unusual, as both adults and larvae were found deep inside Sayu Cave in the Shai Hills (Orozco and Philips, 2012).

In summary, it is likely that many of the insects we recorded can be found outside of these cave habitats. Hence the invertebrate cave fauna of Ghana may not be extremely unusual or exhibit endemicity to any great degree, and they may be found in additional caves or other non-cave environments. In regard to cave conservation, many of the village elders and chiefs discussed with us the tourism potential of caves in the vicinity of their villages as a possible source of revenue. Unfortunately, many of the caves are small, difficult to access, often quite malodorous, and only esoterically interesting to a few people. Nevertheless, some caves, in addition to those at Likpe, do have potential for the adventure-tourism niche. Regardless, the biodiversity of these caves, including the vertebrates, is a part of the natural heritage of Ghana, and care should be taken to ensure that the fauna is protected and disturbance is minimized.

\section{ACKNOWLEDGEMENTS}

We first and foremost thank the assistance of the following cave guides: Kwasi Kumnipa, Benjamin Nyarko, Benjamin Tachie-Menson, Nanatakyi-Abiam, Justice (Ameyaw) Konadu, Johnson Tulasi, Koku "Frank" Asibe, Joshua K. Sokpah, Godwin K. Sokpah, Christian Adae, Rebecca Okuara, Godson Asigbedse, Nestor Kpordzih, A.K. Marfo, and Goldan David. We also thank Kingsley Osei (Shai Hills Reserve director) for his hospitality and for generously providing lodging during our visit to the reserve. A research permit from Cletus K. Nateg, Director of the Forestry Commission and Mike Adu-Asiah, Senior Wildlife Officer with the Forestry Commission, Wildlife Division, as well as permission from many village chiefs and elders, enabled us to visit these caves. We also appreciate the following individuals with their help at identifying species: Kipling Will (University of California, Berkeley); Darren Mann (Hope Entomological Collections at the Oxford University Museum of Natural History); Laure Desutter-Grandcolas (Muséum National d'Histoire naturelle); Kurt Helf (National Park Service Cumberland Piedmont Network, Mammoth Cave, KY) and Bruce Gill (Agriculture Canada, Ottawa). We also appreciate the useful comments from Kurt Helf and one anonymous reviewer. Lastly, this work also would not have been possible without the support of a National Science Foundation Biological Surveys and Inventories grant (DEB- 0430132) for which we are extremely grateful. This research was part of a Master's of Science thesis by the second author.

\section{REFERENCES}

Bourgies, F. and Juberthie, C., 2001, Burkina Faso, in Juberthie, C. and Decu, V., eds., Encyclopaedia Biospeologia, Tome III: Moulis and Bucarest, Société Internationale de Biospéologie, p. 1505-1506.

Conservation International, n.d., The Biodiversity Hotspots: http://www. conservation.org/How/Pages/Hotspots.aspx [accessed June 20, 2015].

Critical Ecosystem Partnership Fund, n.d., Guinean Forests of West Africa: http://www.cepf.net/resources/hotspots/africa/Pages/GuineanForests-of-West-Africa.aspx [accessed June 20, 2015].

Harrison, P., and Pearce, F., 2001, AAAS Atlas of Population and Environment: Berkeley, California, University of California Press, 215 p.

Howarth, F.G., 1983, Ecology of cave arthropods: Annual Review of Entomology, v. 28, p. 365-389. doi:10.1146/annurev.en.28.010183.002053.

Juberthie, C., and Decu V., eds., 2001, Encyclopaedia Biospeologia, Tome III: Moulis and Bucarest,Société Internationale de Biospéologie, p. 1381-2294.

Orozco, J. and Philips, T. K. 2012, Pachnoda marginata (Drury) (Coleoptera: Scarabaeidae: Cetoniinae) developing in bat guano in a West African Cave: Coleopterists Bulletin, v. 66, 378-379. doi:10.1649/072.066.0417.

Romero, A., 2009, Cave Biology, Life in Darkness: New York, Cambridge University Press, $291 \mathrm{p}$.

Roth, L.M., and Naskrecki, P., 2004, A new genus and species of cave cockroach (Blaberidae: Oxyhaloinae) from Guinea, West Africa: Journal of Orthoptera Research, v. 13, p. 57-61. doi:10.1665/10826467(2004)013[0057:ANGASO]2.0.CO;2.

Villiers, A., 1953, Emesinae cavernicoles du Congo belge (Hemiptera Reduviidae): Revue de zoologie et de botanique africaines, v. 47, p. 31-33.

Villiers, A., 1973, Hémiptères réduviides cavernicoles du Sud-Ouest africain: Revue Suisse de Zoologie, v. 80, p. 573-576.

Villiers, A., 1976, Hémiptères Reduviidae des grottes du Kenya (Mission V. Aellen et P. Strinati): Revue Suisse de Zoologie, v. 83, p. 765-768. 